\title{
A case for formalizing subseries (subepochs) of the Cenozoic $\operatorname{Era}^{(\mathbf{a})}$
}

\author{
${ }^{1}$ Department of Earth Sciences, Brock University, 1812 Sir Isaac Brock Way, St. Catharines, Ontario L2S 3A1, Canada. Corresponding author, \\ E-mail:mjhead@brocku.ca \\ ${ }^{2}$ Department of Earth and Planetary Sciences, Rutgers University, Piscataway NJ 08854, USA. E-mail: aubry@rci.rutgers.edu; kgm@rci.rut- \\ gers.edu \\ ${ }^{3}$ School of Archaeology, History and Anthropology, Trinity Saint David, University of Wales, Lampeter, Wales, SA48 7ED, UK. E-mail: $m$. \\ walker@uwtsd.ac.uk \\ ${ }^{4}$ Department of Geography and Earth Sciences, Aberystwyth University, Aberystwyth, Wales, SY23 3DB, UK \\ ${ }^{5}$ Department of Geological Sciences, University of Saskatchewan, Saskatoon SK7N 5E2, Canada.E-mail: brian.pratt@usask.ca
}

(Received: December 17, 2015; Revised accepted: August 12, 2016)

http://dx.doi.org/10.18814/epiiugs/2017/v40i1/017004

Subseries/subepochs (e.g., Lower/Early Eocene, Upper/ Late Pleistocene) have yet to be formally defined despite their wide use in the Cenozoic literature. This has led to concerns about the stability of their definition and uncertainty over their status that has led to inconsistencies in capitalization. To address these issues, we propose for the Cenozoic that subseries/subepochs be defined formally by reference to Global Boundary Stratotype Sections and Points and ratified in the same way as for other formal chronostratigraphic units. Formalization of subseries/subepochs for the Cenozoic will respect their deep historical roots, recognise their chronostratigraphic nature, stabilize their definition, ensure consistency in application, embrace their de-facto use as formal terms within the Paleogene, Neogene and especially Quaternary communities, and resolve the question of capitalization: an upper-case initial letter without exception.

\section{The case for Cenozoic subseries/subepochs}

Subseries/subepochs (e.g., Lower/Early Eocene, Upper/Late Pleistocene) are not formally recognised by the International Commission on Stratigraphy (ICS) despite their wide use in the Cenozoic literature and sanction by the International Stratigraphic Guide (Hedberg, 1976, p. 72, tab. 2; Salvador, 1994, p. 80, tab. 3). Yet the concept of subdividing series/epochs (hereafter "series") is as old as the series themselves, and dates back to the work of Charles Lyell (1833). Divisions of series predate stages, which became systematically incorporated into the Cenozoic time scale only in the 1970s, with the boundaries of stages adjusted to fit subseries, not the other way around. Aubry (2016) provides a comprehensive history of the subdivision of series for the Cenozoic and their relationship to stages, the broader history of chronostratigraphy having been outlined by Aubry et al. (1999) and Vai (2007).

The ICS-imprinted Global Stratigraphic Chart of 1989 (Cowie and Bassett, 1989) included divisions of series for the Neogene and Quaternary [There was no subdivision of the Paleogene series because the ICS Subcommission on Paleogene Stratigraphy (SPS) was still working on this (Aubry, 2016)]. While significant as an indication of notional acceptance of subseries by ICS, this would not be an explicit approval of subseries, and such divisions have not since appeared on explicitly sanctioned ICS charts. Even so, announcements of global boundary stratotype sections and points (GSSPs) published in the journal Episodes frequently contain references to subseries for the Cenozoic, and the positional terms "Lower/Early", "Middle", and "Upper/Late"are applied to all series of the Cenozoic: their use in the literature is pervasive. They are treated as formal terms when the initial letter is in upper-case (e.g., Upper Eocene), or informal when in lower-case (e.g., upper Eocene), but this decision is often imposed by no more than editorial fiat and house style. Cenozoic subseries are used always in reference to a ratified or anticipated GSSP: they are de-facto chronostratigraphic units, as we explain below (point 14). We therefore use upper-case for these terms in the present paper.

The lack of official definition of subseries for the Cenozoic has nonetheless led to: 1) uncertainty about their status (formal or informal) leading to inconsistencies in capitalization, and 2) concern about the stability of their definition. These issues have caused the status of Cenozoic subseries to be discussed within ICS. Two distinct positions have emerged:

(a) In order to determine the level of support within the three relevant ICS subcommissions (SPS, SNS, and SQS) for the formalization of subseries in the Cenozoic, a ballot was held among all voting members of these subcommissions. This paper is the position statement for formalization, and was circulated on June 21, 2016, along with the other voting materials. Figure 2 is included here because it had been part of an earlier version, but did not appear in the circulated document. The position statement as circulated included the ICS affiliations of the authors: Martin J. Head, Chair, Subcommission on Quaternary Stratigraphy (SQS); Marie-Pierre Aubry, Voting Member, Subcommission on Neogene Stratigraphy (SNS); Mike Walker, Voting Member, SQS; Kenneth G. Miller, Vice-Chair, SNS; Brian R. Pratt, Chair, Subcommission on Stratigraphic Classification. 
1) the continuance of "informal" status with no position taken by ICS, so that individual authors are free to make their own decisions about subseries definitions (the status quo); but with clarification placed on the ICS website to indicate that subseries are to be treated as informal and indicated as such with a lower-case initial letter;

2) our own position in which subseries are treated as defined, ratified and hence formal chronostratigraphic units for the Cenozoic.

The first position (status quo) would perpetuate all the problems we are trying to resolve: uncertainty in the application of subseries, instability in their definition, denial of their actual chronostratigraphic status, and continued divergence in the practice of capitalization especially within the Quaternary community.

The second position (this proposal) requires that subseries definitions for the Cenozoic be accomplished in the usual way for formal chronostratigraphic units: a proposal by the relevant subcommission, approval by the voting membership of ICS, and ratification by the Executive Committee (EC) of the International Union of Geological Sciences (IUGS). Ratification is the essential final step, providing oversight and legitimacy to the entire process. A commonly used grouping of stages into subseries is shown (Fig. 1). But there are alternative schemes, and we argue that these subseries must be formally defined to ensure their legitimacy and stability. Nonetheless, we recommend that formal subseries do not appear on the International Chronostratigraphic Chart, but instead reside on a more detailed auxiliary chart displayed on the ICS website. This will preserve the simplicity and integrity of the main chart. We make the following additional observations:

1. The historical legitimacy of subseries as chronostratigraphic units is incontestable. The subdivision of series is as old as the series themselves, and dates back to Lyell (1833) with his Older and Newer Pliocene and the anticipated subdivision of his other series, Eocene and Miocene (Lyell, 1833, pp. 57, 58). Lyell (1833, p. 53, 54) used uppercased initial letters for his Older and Newer Pliocene presumably to stress their formal standing, although he did this somewhat inconsistently as with other terms. However, by 1838 he was using these terms persistently in upper case. In 1855, Lyell published what is probably the first-ever multi-hierarchical chronostratigraphic chart (Lyell, 1855, p. 109, Fig. 2). All terms are set fully in upper case in this chart; but elsewhere in the text he typically upper-cased initial letters of all positional modifiers, including Lower Silurian, Upper Silurian, Lower Cretaceous, Upper Cretaceous, and significantly Lower Eocene, Middle Eocene, Upper Eocene, Lower Miocene, and Upper Miocene. In 1857, Lyell discussed the Middle Miocene with reference to an earlier publication (by V. Raulin), and also Lower, Middle, and Upper Oligocene with respect to the newly introduced "Oligocene" of Beyrich (1854), in all cases using upper-cased initial letters. There can be little doubt that Lyell intended these as formal subdivisions.

The subdivision of series in fact predates stages for the Cenozoic, with for example Mayer (in Gressly, 1853) assigning his Aquitanian Stage to the Lower Miocene. The GSSP concept, inaugurated at the $18^{\text {th }}$ International Geological Congress in 1948, was first applied to the Pliocene-Pleistocene boundary, with the Upper Pliocene and Lower Pleistocene (initial letters capitalized in the original) being specifically mentioned along with the Calabrian (regional) Stage (King and Oakley, 1949). It was not until the 1970s (Berggren, 1971, 1972) that

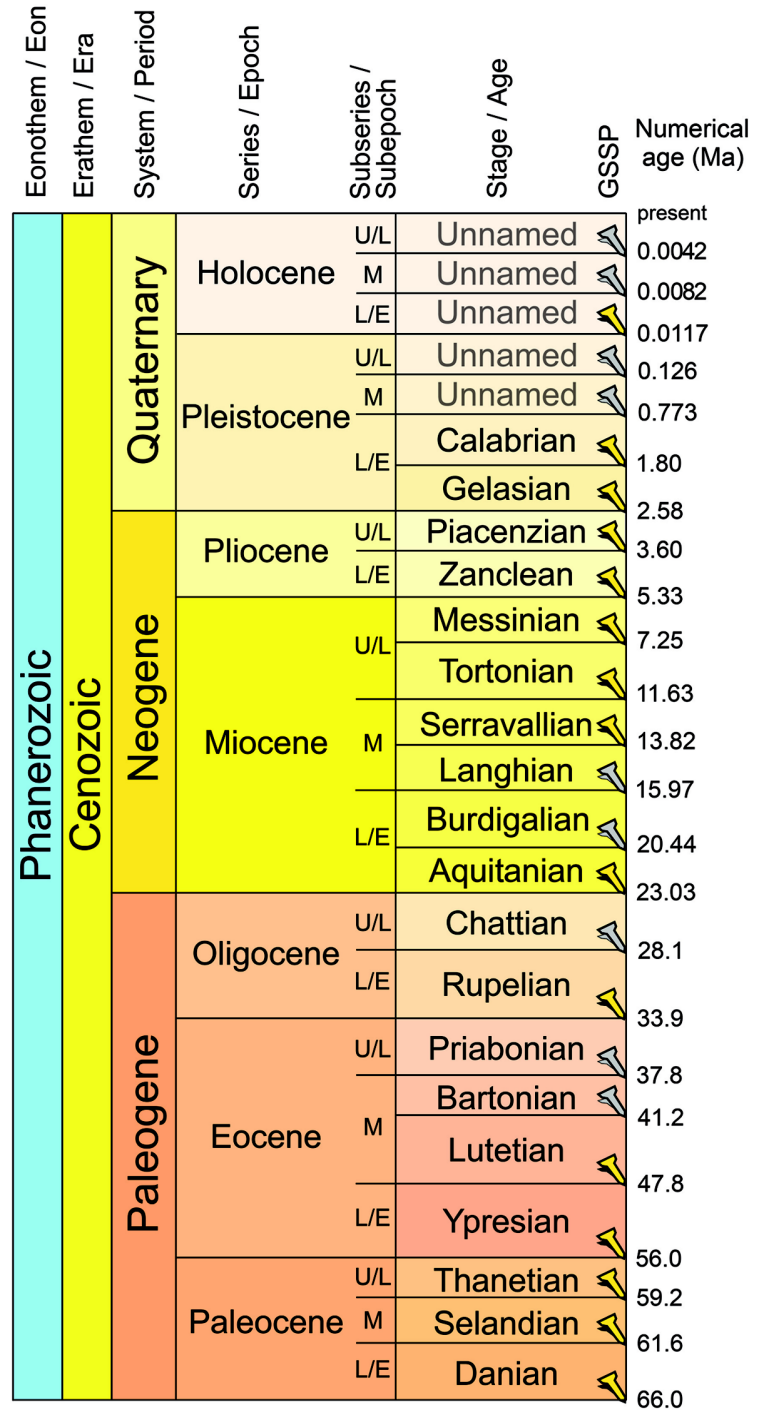

Figure 1: The Cenozoic part of the International Chronostratigraphic Chart (modified from Cohen et al., 2013, v. 2016/04) showing the subseries/subepoch scheme following Luterbacher et al. (2005) for the Paleogene, and Lourens et al. (2005) for the Neogene, except that the Quaternary follows Gibbard et al. (2010) and Head and Gibbard (2015). The tripartite subdivision of the Holocene Series is long established (Walker et al., 2012). Its subdivision into Early, Middle and Late Holocene subepochs and their corresponding ages/stages, at 8.2 and $4.2 \mathrm{ka}$, has been recommended by the SQS. Abbreviations: $L / E=$ Lower/Early, $M=$ Middle, $U / L=U$ Uper/Late, all capitalized to indicate units of formal rank. Golden spikes are ratified GSSPS, grey spikes are pending. For each "unnamed” Quaternary Stage, a geographically based name will be proposed along with its corresponding subseries/subepoch. This figure is for illustrative purposes only: we recommend that subseries divisions do not appear on the International Chronostratigraphic Chart but be placed on a separate detailed auxiliary chart maintained on the ICS website (see point 15).

Cenozoic stages became systematically incorporated into the time scale (Aubry et al., 1999), accomplished by adjusting stages to preexisting subseries boundaries. Subseries positional names (Lower/ Middle/Upper) reflect a fundamental tenet of stratigraphy (the Principle of Superposition) and are intuitive and appropriate. Series subdivisions have always been used in a chronostratigraphic context, regardless 


\section{ABRIDGED TABLE OF FOSSILIFEROUS STRATA.}

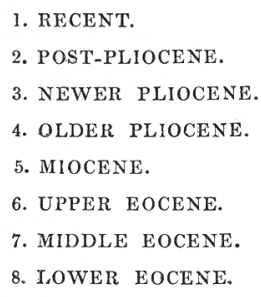

cene designation, in turn causing the Middle Pliocene Piacenzian Stage to become Upper Pliocene. The Gelasian is nonetheless now stabilized and a unique case that seems unlikely to be repeated.

2. It has been pointed out that the Integrated Ocean Discovery Program (IODP) and its predecessors, the Ocean Drilling Program (ODP) and the Deep Sea Drilling Project (DSDP), and the United States Geological Survey, have instructed authors not to capitalize the modifiers early/middle/late with respect to subseries because they are not formally defined by the ICS. We see this not so much as evidence for the support of informal subseries, but rather a passive editorial compliance with the status quo. We note that the IODP is only a subset of a wider geoscience community that includes the study of shallow-marine, terrestrial, and lacustrine deposits, and ice-cores. More significant to us are examples (see Aubry, 2016, and point 3 below) where subseries terms are capitalized to confer formal meaning even without ICS sanction. We note that subseries are frequently capitalized in several Quaternary (e.g., Boreas, Journal of Quaternary Science, Quaternary International) and petroleum geoscience (e.g., Marine and Petroleum Geology) journals and other geoscience journals. In the two most recent editions of the Geologic Time Scale, the influential Quaternary chapters (Gibbard and van Kolfschoten, 2005; Pillans and Gibbard, 2012) both use upper-case subseries terms almost exclusively. The equally influential global chronostratigraphic correlation table for the Quaternary (Gibbard and Cohen, 2008, and subsequent updates), including the 2010 version of this table which currently appears on the ICS website, all depict upper-case subseries terms. We contend that even in the absence of formal definition, many authors prefer to use subseries in the formal sense.

3. Subseries are frequently referenced in descriptions of Cenozoic GSSPs in the journal Episodes, and are often written with an initial capital letter to indicate formal use. The Middle Paleocene, Upper Paleocene, Middle Eocene, Upper Eocene, Middle Miocene, Upper Miocene, Lower Pliocene, Upper Pliocene, and Lower Pleistocene are all cited in this way (see Aubry, 2016, appendix 1 for details). The Middle Pleistocene and Upper Pleistocene have yet to be proposed, and the Lower, Middle and Upper Holocene are in progress, but these too are intended as formal terms (see point 6, below).

4. The rank of subseries is given support without specific qualification in the International Stratigraphic Guide (Hedberg, 1976, p. tab. 2; Salvador, 1994, p. 80, tab. 3), unlike sub- and superstages where "restraint is recommended ... to avoid complicating the nomenclature unnecessarily" (Salvador, 1994, p. 80). The Guide does in general recommend restraint in using sub- and super- for new ranks (Salvador, 1994, tab. 1), but this could apply equally to the rank of subsystem/ subperiod, which is in fact sanctioned for the Carboniferous System (Metcalfe, 2000). The ICS statutes (www.stratigraphy.org/index.php/ ics-statutesofics) make no specific judgment on subseries, simply stating that "formal stratigraphic stage names and units of higher rank" may be ratified by the IUGS.

5. The very fact that subseries have been treated both formally and informally speaks to the need for clear and universally agreed definition. This can only be accomplished by defining subseries explicitly ered in 2009 (Gibbard and Head, 2010), it incorporated the Gelasian Stage which then changed from an Upper Pliocene to Lower Pleisto- 
with ratified GSSP boundaries, rendering them as formal units. By so doing, the perennial issue of whether Lower/Early, Middle, and Upper/Late should be in upper-case will be resolved permanently.

6. The Quaternary has no enduring tradition of international stages: the Gelasian Stage was ratified only in 1996 and the Calabrian Stage in 2011, with no additional stages yet defined. Subseries have therefore long acquired special prominence. The positional terms Lower, Middle and Upper Pleistocene have been used continuously since the 1930s (Head and Gibbard, 2015), are now unambiguously defined, and are treated as formal terms in the Quaternary literature and by the International Union for Quaternary Research (INQUA). More widely employed by the Quaternary community are the equivalent subepochs (Early, Middle, Late). These subseries/subepochs nonetheless require sanction by GSSP and IUGS ratification, and SQS has the following boundary working groups explicitly tasked with this purpose: the Early/ Middle Pleistocene Working Group, the Middle/Late Pleistocene Working Group, and the Working Group on the Formal Subdivision of the Holocene. A proposal by the last of these to subdivide the Holocene Series into Lower, Middle and Upper Holocene subseries (Early, Middle, Late subepochs), with corresponding stages, has been recommended with an $81 \%$ majority by the SQS. Hence, the formal subdivision of the Quaternary into subseries/subepochs, and their corresponding stages, is well advanced (Head and Gibbard, 2015). Regarding Holocene subdivision, many practitioners (geographers, archaeologists, environmental and climate scientists etc.) are not trained geoscientists. Some may use the stage names we are proposing, but most will use subseries (or rather subepochs) formally for the Holocene regardless of whether we officially recognize them or not (Walker et al., 2012). This is long-established practice, and we have little control over it.

7. Quaternary stratigraphers make use of geochronology universally. They present their data in terms of time and thus naturally use the terms Early, Middle and Late. For example, annual/seasonal layering in ice cores, speleothems, and lacustrine and anoxic marine records, and growth bands in shells and wood, all give absolute ages by direct counting from the present. The base of the Holocene itself is dated in this way (Walker et al., 2009). These records typically show data relative to a time scale in years before present, not core or sediment depth. Geochronometry is used routinely in the study of Quaternary sedimentary successions: radiocarbon dating, lead-210 dating, thermoluminescence dating, and numerous other techniques all give age estimates in years before present (or a proxy for the present). Since the 1960s, astrochronology has extended this approach into deeper Quaternary time (and of course into the Neogene and even Paleogene) by counting rhythmic sedimentary successions and their isotopic signatures, and calibrating them to mathematical solutions for orbital forcing. Data from Pliocene and Pleistocene oceanic successions are typically shown relative to years before present, not core depth. Geochronology is pervasive in Quaternary stratigraphy, whereas traditional stratigraphy is hampered by the extreme climatic gradients that emerged at this time. Subseries/subepoch terminology is accordingly widespread in the Quaternary literature, which is why these terms need to be formally defined.

8. INQUA is a full Scientific Union member of the International
Council for Science, together with the IUGS. INQUA has long shared responsibility with ICS for the Quaternary part of the International Geological Time Scale, and was active in its formal definition (Finney, 2010; Gibbard and Head, 2010; Head and Gibbard, 2015). Until 2001, its Commission on Stratigraphy also served as the de-facto SQS but with its officers appointed by INQUA. Although the structure of SQS was brought in line with other ICS subcommissions in 2001, INQUA remains actively involved with its portion of the time scale (Head and Gibbard, 2015). For example, the Working Group on the Formal Subdivision of the Holocene is a joint working group of SQS and the INQUA international focus group INTIMATE (Walker et al., 2012). INQUA's opinion is important. While INQUA embraces the use of international stages for the Quaternary, its position on subseries is clear. INQUA supports without reservation the case for formal subseries/subepochs for the Quaternary, and indeed already treats this rank as a formal term.

9. ICS-recognized working groups on the Middle and Upper Pleistocene have been in existence since at least 1989 (Cowie and Bassett, 1989). ICS has already supported formal subseries for the Quaternary. A proposal for a Lower Pleistocene Subseries GSSP in 2008 (Litt et al., 2008) was considered by SQS which voted unanimously in support (18 in favour, 2 not responding), reflecting the need for subseries in the Quaternary. This proposal was then approved by ICS with a majority of $71 \%$ (10 in favour, 4 against; Ogg and Bowen, 2008). None of those voting against cited the introduction of subseries as problematic. The IUGS EC declined to ratify this proposal citing eight objections, of which one was that "restraint is recommended in creating new orders of chronostratigraphic units, as sub-erathem, subsystem, sub-series and sub-stage" (Riccardi, 2008), which brings us to the present discussion. Nonetheless, voting within ICS had demonstrated overwhelming support for subseries, at least for the Quaternary. It should be noted that the need for formally defined subseries for the Quaternary was recognized by the ICS Executive as early as 2001 (P.L. Gibbard in Ogg and Bowen, 2008), and SQS has made the definition of subseries a focus of its annual science plan consistently since 2003 (see SQS website), with no objection ever having been raised by the ICS Executive. The widely distributed Quaternary correlation chart (Cohen and Gibbard, 2010), e.g., as posted on the ICS website, illustrates the fundamental use of subseries for the Pleistocene. Even the current International Chronostratigraphic Chart (Cohen et al., 2013, version 2016/04) uses the terms "Middle" and "Upper" as placeholders for Pleistocene stage names (yet to be defined), which certainly Quaternarists would consider as referencing the widely used subseries for the Pleistocene.

10. The ICS open meeting at the Second International Congress on Stratigraphy in Graz in July 2015 was held to gauge opinion on the formalization of subseries. Positions for and against the adoption of official subseries for the Cenozoic were expressed from the floor, with the great majority speaking in favor of adoption. While this does not constitute a vote on the matter, it must be concluded that adoption of formal subseries was favored among those attending.

11. It is undeniable that the use of subseries creates redundancy, but this is the price one pays for choice. The Middle Eocene, the entire 
Miocene, and the Lower Pleistocene all benefit from the availability of subseries.

12. Stages, not subseries, are the fundamental units of chronostratigraphy. However, concern that stages will decline in use if subseries are formalized is overstated (see also point 15 below). Although subseries are already pervasive in the literature, this has not diminished the use of stages. But whether subseries are given formal sanction (by IUGS-EC ratification, as we propose) or left undefined, practitioners will continue to use the terms they find most useful and appropriate. As demonstrated in Aubry (2016), the only other alternative to the present confusion would be to suppress subseries, but this of course is not an option.

13. Stages and subseries are mostly used to express different levels of chronostratigraphic precision and certainty. For example, deposits of imprecisely known age could be expressed as "Lutetian and/or Bartonian", or more ambiguously as "Lutetian-Bartonian"; but "Middle Eocene" is more efficient and elegant. Likewise, "Middle Eocene cooling" is clearer than "Lutetian-Bartonian cooling" (see Aubry, 2016, for additional examples). Subseries are more frequently used by terrestrial and shallow-marine workers than stages because the stratigraphy is often discontinuous and its dating therefore less precise. However, we contend that stages and subseries are both useful, allow necessary flexibility, and warrant full official definition and recognition.

14. A capital initial letter identifies that a chronostratigraphic term is formal and represents a defined interval of time. Subseries are defined by GSSP, and therefore are intrinsically chronostratigraphic and formal in a general sense. The International Stratigraphic Guide (ISG; Salvador, 1994, p. 7, 8) recognises chronostratigraphic units as formal units. Moreover, the ISG considers formal stratigraphic terms those that are "properly defined and named according to an established or conventionally agreed scheme of classification", and in such cases capitalization of the initial letter is required (Salvador, 1994, p. 14). According to the North American Stratigraphic Code (North American Commission on Stratigraphic Nomenclature, 2005), formal units (indicated by capitalization) are those named in accordance with an established classification scheme. The terms "uppermost Oligocene" or "lower Quaternary" are immediately and correctly recognised as having no strictly defined duration: they are informal. The ISG uses "late Quaternary" to indicate the last 50 to $70 \mathrm{kyr}$ of Earth history (Salvador, 1994, p. 88). To lowercase a subseries term, such as "lower Miocene", wrongly implies that it is not strictly defined. The term "lower Lower Eocene" immediately distinguishes between the first "lower" which has no strictly defined duration, and the second "Lower" which does (Aubry, 2016).

15. We recognise the desirability for the main International Chronostratigraphic Chart (Cohen et al., 2013) to have an uncluttered appearance. Accordingly, we recommend that formal subseries not appear on this main chart but feature instead on a more detailed auxiliary chart maintained on the ICS website. Hence the simplicity and aesthetic value of the main chart will not be compromised by the formalization of subseries, as it will continue to display the cardinal ranks exclusively. This also means that stages, which are the fundamental building blocks of chronostratigraphy, will continue to receive the prominence they merit because on the main chart they will not be competing with, or overshadowed by, subseries.

In closing, we advocate defining subseries in the Cenozoic by formal IUGS-EC ratification to stabilize the use of these terms and circumvent a two-tier system of legitimacy for chronostratigraphic units. Formal status will respect the deep historical roots of subseries for the Paleogene and Neogene, and provide legitimacy for a system in universal use within the Quaternary community that already treats subseries/subepochs as formal units. Our proposal respects the primacy of stages as the fundamental building blocks of chronostratigraphy, but acknowledges the chronostratigraphic legitimacy of subseries. Formalization will also provide a final resolution to the capitalization conundrum: upper case without exception for the positional terms Lower/Early, Middle, and Upper/Late throughout the Cenozoic.

\section{Acknowledgements}

We are grateful to Jan A. Piotrowski, Gian Battista Vai, and Jan Zalasiewicz for their constructive reviews of an earlier version of the MS, and Stanley C. Finney (Chair of ICS) for his incisive comments on this proposal. MJH acknowledges support from a Discovery Grant of the Natural Sciences and Engineering Research Council of Canada.

\section{References}

Aubry, M.-P., 2016, Cenozoic chronostratigraphic terminology: In defense of formal subseries: Stratigraphy, v.13, pp. 1-20.

Aubry, M.-P., Berggren, W.A., Van Couvering, J.A., and Steininger, F., 1999, Problems in chronostratigraphy: Stages, series, unit and boundary stratotypes, GSSPs and tarnished golden spikes: Earth Science Reviews, v.46, pp. 99-148.

Berggren, W.A., 1971, Tertiary boundaries and correlations, in Funnell, M.B. and Riedel, W.R., eds., The Micropalaeontology of Oceans: Cambridge, Cambridge University Press, pp. 693-809.

Berggren, W.A., 1972, A Cenozoic time scale; some implications for regional geology and paleobiogeography: Lethaia, v.5, pp. 195-215.

Beyrich, E., 1854, Über die Stellung der Hessichen Tertiärbildinger: Berichte von der Verhandlugen der Königliche Preussische Akademie der Wissenschaft zu Berlin, p. 640-666.

Cohen, K.M., and Gibbard, P.L., 2010, Global chronostratigraphical correlation table for the last 2.7 million years, v. 2010. ICS website, http:/ /www.stratigraphy.org/index.php/ics-chart-timescale [Accessed June 9, 2016]. This chart is updated from Gibbard and Cohen (2008).

Cohen, K.M., Finney, S.C., Gibbard, P.L., and Fan, J.-X., 2013, The ICS International Chronostratigraphic Chart: Episodes, v.36, pp. 199-204. [Version 2016/04, ICS website, http://www.stratigraphy.org/index.php/icschart-timescale; accessed June 9, 2016]

Cowie, J.W., and Bassett, M.G. (compilers), 1989, 1989 global stratigraphic chart with geochronometric and magnetostratigraphic calibration: Episodes, v.12, no.2, supplement, 1 sheet.

Finney, S.C., 2010, Formal definition of the Quaternary System/Period and redefinition of the Pleistocene Series/Epoch: Episodes, v.33, no.3, pp. 159-163.

Gibbard, P.L., and Cohen, K.M. 2008, Global chronostratigraphical correlation table for the last 2.7 million years: Episodes, v.31, pp. 243-247.

Gibbard, P.L., and Head, M.J., 2010, The newly-ratified definition of the Quaternary System/Period and redefinition of the Pleistocene Series/ Epoch, and comparison of proposals advanced prior to formal ratifi- 
cation: Episodes, v.33, no.3, pp. 152-158.

Gibbard, P., and van Kolfschoten, T., 2005, The Pleistocene and Holocene epochs, in Gradstein, F.M., Ogg, J.G., and Smith, A.G., eds., A Geologic Time Scale 2004: Cambridge, Cambridge University Press, pp. 441-452 [Imprinted 2004].

Gibbard, P.L., Head, M.J., Walker, M.J.C., and The Subcommission on Quaternary Stratigraphy, 2010, Formal ratification of the Quaternary System/Period and the Pleistocene Series/Epoch with a base at 2.58 Ma: Journal of Quaternary Science, v.25, no.2, pp. 96-102.

Gressly, A., 1853, Nouvelles données sur les faunes teriaires d'Ajoie, avec les déterminations de M. Mayer: Actes de la Société helvétique des sciences naturelles, v.38, pp. 251-261.

Head, M.J., and Gibbard, P.L., 2015, Formal subdivision of the Quaternary System: Past, present, and future: Quaternary International, v.383, pp. 4-35.

Hedberg, H.D. (ed.), 1976, International Stratigraphic Guide: New York, John Wiley and Sons, $200 \mathrm{p}$.

King, W.B.R., and Oakley, K.P., 1949, Definition of the Pliocene-Pleistocene boundary: Nature, v.163, pp. 186-187.

Litt, T., Bettis III, E.A., Bosch, A., Dodonov, A., Gibbard, P., Liu Jiaqui, Kershaw, P., von Koenigswald, W., McManus, J., Partridge, T., and Turner, C., 2008, A proposal for the Global Stratotype Section and Point (GSSP) for the Middle/Upper (Late) Pleistocene Subseries Boundary (Quaternary System/Period). Submitted to the International Commission on Stratigraphy, 34 p. [Unpublished]

Luterbacher, H.P., Ali, J.R., Brinkhuis, H., Gradstein, F.M., Hooker, J.J., Monechi, S., Ogg, J.G., Powell, J., Röhl, U., Sanfilippo, A., and Schmotz, B., 2005, The Paleogene Period, in Gradstein, F.M., Ogg, J.G., and Smith, A.G., A Geologic Time Scale 2004: Cambridge, Cambridge University Press, pp. 384-408. [Imprinted 2004].

Lourens, L., Hilgen, F., Shackleton, N.J., Laskar, J., and Wilson, D., 2005, The Neogene Period, in Gradstein, F.M., Ogg, J.G., and Smith, A.G., A Geologic Time Scale 2004: Cambridge, Cambridge University Press, pp. 409-440. [Imprinted 2004].

Lyell, C., 1833, Principles of geology: London, John Murray. Vol. 3, 1833, 398 p. +160 p. appendices.

Lyell, C., 1838, Elements of geology: London, John Murray, pp. i-xix, 1543.

Lyell, C., 1855, A manual of elementary geology (Fifth edition): London, John Murray, pp. i-xvi, 1-655.

Lyell, C., 1857, Supplement to the fifth edition of a manual of elementary geology (Second edition), revised: London, John Murray, pp. 1-40.10

Metcalfe, I., 2000, Secretary/Editor's report 1999-2000: Newsletter on Carboniferous Stratigraphy, v.18 (July 2000), pp. 2-3. IUGS Subcommission on Carboniferous Stratigraphy.

North American Commission on Stratigraphic Nomenclature, 2005, North American stratigraphic code: AAPG Bulletin, v.89, pp. 1547-1591.

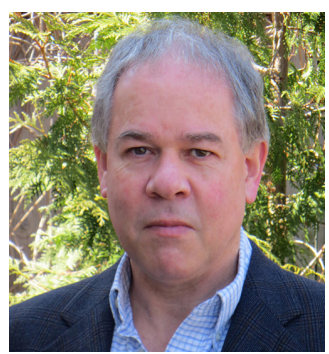

Martin J. Head is a Professor of Earth Sciences at Brock University in Canada, a position held since 2005 . He was previously at the University of Cambridge, and before that the University of Toronto where he maintains an affiliation. He is serving a second term as Chair of the International Subcommission on Quaternary Stratigraphy (until 2020), and is Co-Convener of its Working Group on the Lower-Middle Pleistocene Subseries Boundary. He is also a member of the INQUA Commission on Stratigraphy and Chronology. His interests include late Cenozoic stratigraphy, paleoceanography, and marine palynology; and particularly the late Cenozoic record of dinoflagellate cysts and acritarchs. Martin holds a PhD from the University of Aberdeen, Scotland, UK.
Ogg, J., and Bown, P., 2008, Request for IUGS ratification of the GSSP defining the base of the upper subdivision (subseries) of the Pleistocene Series. Letter to IUGS Secretariat dated 26 August, 2008, 27 p. [unpublished].

Pillans, B., and Gibbard, P., 2012, The Quaternary Period, in Gradstein, F.M., Ogg, J.G., Schmitz, M.D., and Ogg, G.M., The Geologic Time Scale 2012: Oxford, Elsevier, pp. 979-1010.

Riccardi, A.C., 2008, Letter to Dr. Stanley Finney, Chairman, International Commission on Stratigraphy: Dated September 22, 2008, 2 p. [unpublished].

Salvador, A. (ed.), 1994, International stratigraphic guide: A guide to stratigraphic classification, terminology, and procedure (Second edition): International Subcommission on Stratigraphic Classification of IUGS International Commission on Stratigraphy and The Geological Society of America, Boulder, Colorado, pp. i-xix, 1-214.

Vai, G.B., 2007, A history of chronostratigraphy: Stratigraphy, v.4, no.2/ 3, pp. 83-97.

Van Couvering, J.A., McGowran, B., and Berggren, W.A., 2015, Editorial: The value of formal subseries: Stratigraphy, v.12, no.2, pp. i-ii.

Walker, M., Johnsen, S., Rasmussen, S.O., Popp, T., Steffensen, J.-P., Gibbard, P., Hoek, W., Lowe, J., Andrews, J., Björck, S., Cwynar, L.C., Hughen, K., Kershaw, P., Kromer, B., Litt, T., Lowe, D.J., Nakagawa, T., Newnham, R., and Schwander, J., 2009, Formal definition and dating of the GSSP (Global Stratotype Section and Point) for the base of the Holocene using the Greenland NGRIP ice core, and selected auxiliary records: Journal of Quaternary Science, v.24, pp. 3-17.

Walker, M.J.C., Björck, S., Cwynar, L.C., Long, A.J., Lowe, J.J., Newnham, R.M., Rasmussen, S.O., and Weiss, H., 2012, Formal subdivision of the Holocene Series/Epoch: A discussion paper by a working group of INTIMATE (Integration of ice-core marine and terrestrial records) and the Subcommission on Quaternary Stratigraphy (International Commission on Stratigraphy): Journal of Quaternary Science, v.27, pp. 649-659.

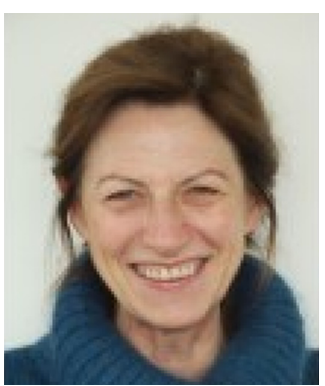

Marie-Pierre Aubry is a Professor in the Department of Earth and Planetary Sciences, Rutgers University, USA. She is currently a voting member of the International Subcommission on Neogene Stratigraphy, and she earlier served on the Paleogene Subcommission. She was Chairman of the ICS Working Group on the Paleocene/Eocene boundary and President of IGCP Project 308. Her interests include Cenozoic stratigraphy and geochronology, major extinction events in the Cenozoic, and the evolution of the marine plankton. She is the author of a multi-volume series on Cenozoic Coccolithophores. She holds a DSc from the University Pierre and Marie Curie in Paris. She was elected an AAA Fellow in 2015.

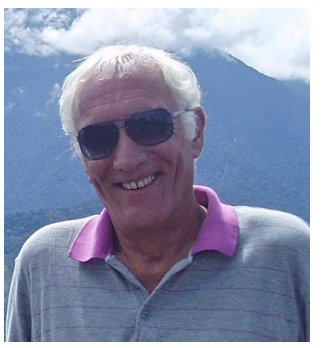

Mike Walker is Emeritus Professor of Quaternary Science, University of Wales, Lampeter, UK and Honorary Professor, Aberystwyth University, UK. He is former President of the Quaternary Research Association of Great Britain, and past Chair of the Natural Environment Research Council Radiocarbon and Cosmogenic Isotopes committees. He chaired the SQS Working Group that defined the PleistoceneHolocene boundary, and is currently chairing the SQS Working Group on the subdivision of the Holocene. His principal research interests are in late Quaternary climate change and its manifestations in proxy records. He has worked extensively on problems of stratigraphy and chronology during the Last Termination. 